\title{
Effect of Insulin Administration on Bone Formation Is Impaired in Rats with Skeletal Unloading
}

\author{
Masayoshi Yamaguchi, ${ }^{* a}$ Seiko Kishi, ${ }^{a}$ and Takeshi HoshI ${ }^{b}$ \\ Laboratory of Metabolism and Endocrinology, Graduate School of Nutritional Sciences, ${ }^{a}$ and Laboratory of Physiology, \\ School of Food and Nutritional Sciences, ${ }^{b}$ University of Shizuoka, 52-1 Yada, Shizuoka City 422, Japan.
}

Received May 14, 1993

The effect of insulin administration on bone formation was investigated in the femoral diaphysis of rats with skeletal unloading. When the femoral-diaphyseal tissues from normal rats were cultured in the presence of insulin $\left(10^{-9}\right.$ and $10^{-8} \mathrm{M}$ ) for $48 \mathrm{~h}$, the hormone produced a significant increase of alkaline phosphatase activity, collagen, deoxyribonucleic acid (DNA) and calcium contents in the bone tissues, indicating that it has a direct stimulatory effect on bone formation. Moreover, when normal rats received a subcutaneous administration of insulin (5.0 IU/100 g body weight) 5 times at 24-h intervals, the hormone caused a significant increase of alkaline phosphatase activity, DNA and calcium contents in the femoral diaphysis. Those increases were not seen by insulin administration to the skeletal-unloading rats with hindlimb hang for $4 \mathrm{~d}$. The present results indicate that the stimulatory effect of insulin on bone formation is lost by skeletal unloading. The finding further supports the view that insulin impairment plays an important role in the deterioration of bone formation by microgravity.

Keywords insulin; bone formation; weightlessness; skeletal unloading; rat femur

It is known that skeletal unloading caused by immobilization, ${ }^{1)}$ spaceflight, ${ }^{2)}$ bed rest, ${ }^{3)}$ or hindlimb elevation ${ }^{4,5}$ results in osteopenia. In growing animals, skeletal unloading result in an inhibition of bone formation, ${ }^{6}$ while in the adult the unloading induces an increase in bone resorption in addition to a decrease in bone formation, and thereby a loss of bone mass. ${ }^{7)}$ The mechanism by which skeletal unloading causes osteopenia is significant in the aspect of bone matabolic regulation.

More recently, it has been demonstrated that an appreciable decrease in alkaline phosphatase activity, protein and deoxyribonucleic acid (DNA) syntheses in the femoral diaphysis of growing rats are induced by hindlimb hang as the model of skeletal unloading, supporting the view that unloading induces an inhibition of bone formation. ${ }^{8,9)}$ Skeletal unloading-induced disorder of bone metabolism may involve a direct gravitational effect in which insulin action is impaired but the hypokinetic condition is not, ${ }^{10}$ ) suggesting that the gravitational effect may be mediated through insulin action.

On the other hand, it is reported that insulin receptors are localized on rat osteoblastic cells. ${ }^{11)}$ Insulin can increase protein phosphorylation, protein and DNA syntheses in osteoblastic cells. ${ }^{12,13)}$ Thus, insulin may play a role in the stimulation of bone formation and calcification, although this remains to be elucidated at the bone tissue level.

The present investigation was undertaken to clarify whether there is a stimulatory effect of insulin on bone formation following hormone administration in rats subjected to skeletal unloading with hindlimb hang. It was found that the effect of insulin administration on bone formation and calcification is impaired in the femoral diaphysis of rats with skeletal unloading in vivo.

\section{Materials and Methods}

Chemicals Dulbecco's modified Eagle's medium (high glucose) and a penicillin-streptomycin solution $(5000 \mathrm{U} / \mathrm{mg}$ penicillin; $5000 \mu \mathrm{g} / \mathrm{ml}$ streptomycin) were obtained from Gibco Laboratories (Grand Island, N.Y., U.S.A.). Bovine serum albumin (fraction V) and insulin (bovine pancreas,
26.2 IU $/ \mathrm{mg}$ ) were obtained from Sigma Chemical (St. Louis, MO., U.S.A.). All other chemicals were reagent grade from Wako Pure Chemical Industries (Osaka, Japan). All water used was glass-distilled.

Animals Female Wistar rats (4 weeks old) were obtained from Japan SLC (Hamamatsu, Japan). The animals were fed commercial laboratory chow (solid) containing $57.4 \%$ carbohydrate, $1.1 \% \mathrm{Ca}$, and $1.1 \% \mathrm{P}$ at a room temperature of $25^{\circ} \mathrm{C}$, and were given distilled water freely.

Bone Culture Rats were bled by cardiac puncture under light anesthesia with ether. The femurs were removed aseptically after bleeding and soaked in ice-cold $0.25 \mathrm{M}$ sucrose solution. The femur was cleaned of soft tissue and marrow, and the diaphysis and epiphysis (containing metaphyseal tissue) were separated. The right femoral-diaphyseal tissues were cut into small pieces. Femoral-diaphyseal fragments were cultured for $48 \mathrm{~h}$ in a $35-\mathrm{mm}$ dish in $2.0 \mathrm{ml}$ medium consisting of Dulbecco's modified Eagle's medium (high glucose, $4.5 \mathrm{~g} / \mathrm{dl}$ ) supplemented with $0.25 \%$ bovine serum albumin plus antibiotics ( 100 units penicillin and $100 \mu \mathrm{g}$ streptomycin $/ \mathrm{ml}$ of medium). ${ }^{12)}$ Cultures were maintained at $37{ }^{\circ} \mathrm{C}$ in a water-saturated atmosphere containing $5 \% \mathrm{CO}_{2}$ and $95 \%$ air.

Skeletal Unloading Rats were placed in a circular cage with a steel-wire floor and fed chow and distilled water freely. ${ }^{7)}$ The hindlimbs were allowed to hang freely but were immobilized with filament tape for up to $4 \mathrm{~d}$. The rats were able to move about in the cage using their forelimbs. The animals were divided into two groups: one group of 5 normal rats was fed and allowed to move around the cage. The 5 rats in the other group with hindlimb hang (skeletal unloading) were fed in a circular cage. Initiation of hindlimb hang was designed for each group so that all animals were the same age at the end of the experiment.

Rats with or without skeletal unloading received a subcutaneous administration of an insulin solution $(5.0 \mathrm{IU} / 0.5 \mathrm{ml} / 100 \mathrm{~g}$ body weight) for $4 \mathrm{~d}$ (once a day). At $5 \mathrm{~d}$, insulin $(5.0 \mathrm{IU} / 100 \mathrm{~g})$ was subcutaneously administered, and $1 \mathrm{~h}$ later the animals were sacrificed at the time point of 11:00 a.m.

Analytical Procedures The separation of collagen from the femoraldiaphyseal tissues was done by the method of Flanagan and Nichols. ${ }^{13)}$ The bone tissues were shaken with $2.0 \mathrm{ml}$ of $0.1 \mathrm{~N} \mathrm{NaOH}$ solution for $16 \mathrm{~h}$ at $4{ }^{\circ} \mathrm{C}$. The tissue remaining after alkaline extraction was further extracted at $4{ }^{\circ} \mathrm{C}$ with contained shaking during three washes in $10 \%$ sodium EDTA solution ( $\mathrm{pH} 7.5$ ) for a total of $48 \mathrm{~h}$ to remove the mineral components. After demineralization, the tissue was washed in water and acetone, and finally reextracted with a mixture of ethanol-ether $(1: 1)$ for $24 \mathrm{~h}$. Following removal of these solvents, the sediment was evaporated to dryness at $105^{\circ} \mathrm{C}$, and $5.0 \mathrm{ml}$ of $6 \mathrm{~N} \mathrm{HCl}$ solution was added to the dried materials. Hydrolyzed samples were evaporated to dryness and taken up in a suitable volume of distilled water. Hydroxyproline was determined by the method of Kivirikko et al. ${ }^{14)}$ Collagen content was expressed as the amount of hydroxyproline $(\mu \mathrm{mol})$ per gram of wet bone tissue.

To measure bone DNA content, the diaphyseal tissues were shaken with $4.0 \mathrm{ml}$ ice-cold $0.1 \mathrm{~N} \mathrm{NaOH}$ solution for $24 \mathrm{~h}$ after the homogenization of 
the bone tissue. ${ }^{13)}$ After alkali extraction, the samples were centrifuged at $10000 \times g$ for $5 \mathrm{~min}$, and the supernatant was collected. DNA content in the supernatant was determined by the method of Ceriott ${ }^{15)}$ and expressed as the amount of DNA (mg)/g wet weight of bone tissue.

The diaphyseal tissues were ashed for $24 \mathrm{~h}$ at $640{ }^{\circ} \mathrm{C}$, weighed, and then dissolved in $6.0 \mathrm{~N} \mathrm{HCl}$ solution. Calcium was determined by atomic absorption spectrophotometry. ${ }^{12)}$ The calcium content in bone was expressed as $\mathrm{mg}$ per $\mathrm{g}$ bone ash.

To assay alkaline phosphatase activity, the diaphyseal tissues were

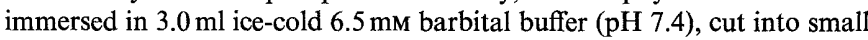
pieces, homogenized with a Physcotron homogenizer, and disrupted for $60 \mathrm{~s}$ with an ultrasonic device. The supernatant centrifuged at $600 \times g$ for $5 \mathrm{~min}$ was used to measure enzyme activity. Enzyme assay was carried out under optimal conditions. Alkaline phosphatase activity was determined by the method of Walter and Schutt. ${ }^{16)}$ Enzyme activity was expressed as $\mu \mathrm{mol}$ of $p$-nitrophenol liberated per min per $\mathrm{mg}$ protein. Protein concentration was determined by the method of Lowry et al. ${ }^{17)}$

Statistical Analysis The significance of the difference between values was estimated by Student's $t$-test. $p$-Values of less than 0.05 were considered to indicate statistically significant differences.

\section{Results}

The effect of insulin on bone components in the femoral-diaphyseal tissues obtained from weanling rats is shown in Table I. These tissues were cultured for $48 \mathrm{~h}$ in a medium containing insulin $\left(10^{-10}-10^{-8} \mathrm{M}\right)$. Insulin at $10^{-9}$ and $10^{-8} \mathrm{M}$ caused a significant increase of alkaline phosphatase activity, collagen, DNA and calcium contents in the tissues, while the hormonal effect was concentrationdependent. Thus, insulin did have a direct stimulatory effect on bone formation in femoral-diaphyseal tissues in vitro.

The effect of insulin in vivo was also examined, and the results are shown in Table II. Insulin $(5.0 \mathrm{IU} / 100 \mathrm{~g}$ body weight) was subcutaneously administered 5 times at 24-h intervals of normal and skeletal-unloading rats; animals were bled $1 \mathrm{~h}$ after the last administration. The administration caused a significant increase of alkaline phosphatase activity, DNA and calcium contents in the femoral diaphysis of normal rats, while skeletal unloading caused a significant decrease of the bone components in comparison with those of normal rats. The administration of insulin to the skeletal-unloading rats with hindlimb hang did not cause an appreciable increase of the bone components in the femoral diaphysis. Thus, skeletal unloading impaired the stimulatory effect of insulin on bone formation in vivo.

\section{Discussion}

Skeletal unloading is known to result in an inhibition of bone formation. ${ }^{5,7,8)}$ The mechanism by which unloading induces osteopenia has not been fully resolved. Previous investigation showed that skeletal unloading with hindlimb hang causes a reduction in bone protein synthesis. ${ }^{7,8)}$ Of various hormones, insulin action is uniquely impaired in the femoral-diaphyseal tissues obtained from skeletalunloading rats ${ }^{18}$; , this impairment is reversed by the removal of the unloading. ${ }^{18)}$ Thus, the impairment of insulin action involves a direct gravitational effect, ${ }^{9,18)}$ although this mechanism remains to be elucidated. These observations suggest that insulin impairment plays an important role in the deterioration of bone formation with skeletal unloading.

The physiologic effect of insulin to stimulate bone formation and calcification is not fully understood, although it has been reported that insulin receptors are localized on rat osteoblastic cells and that the hormone can increase protein and DNA syntheses in these cells. ${ }^{10,11,19)}$ Therefore, the present investigation was undertaken to clarify whether insulin can stimulate bone formation and calcification in the bone tissue culture system, and also whether the hormonal effect is seen with insulin administration to rats without or with skeletal unloading.

The presence of insulin $\left(10^{-9}\right.$ and $\left.10^{-8} \mathrm{M}\right)$ caused a significant increase of alkaline phosphatase activity, collagen, DNA and calcium contents in the tissue culture system using the femoral-diaphyseal tissues obtained from weanling rats, demonstrating that the hormone has a stimulatory effect on bone formation in tissue culture in vitro. The effect of insulin to increase bone alkaline phosphatase activity was completely abolished in the presence of $10^{-6} \mathrm{M}$ cycloheximide (data not shown), suggesting that this effect is involved in protein synthesis. Moreover, the administration of insulin produced a significant increase of alkaline phosphatase activity, DNA and calcium contents in the femoral diaphysis of normal

TABLE I. Effect of Insulin on Bone Components in the Femoral Diaphysis Obtained from Rats in Vitro

\begin{tabular}{|c|c|c|c|c|}
\hline Treatment & $\begin{array}{l}\text { Alkaline phosphatase } \\
(\mu \mathrm{mol} / \mathrm{min} / \mathrm{mg} \text { protein })\end{array}$ & $\begin{array}{c}\text { Collagen } \\
(\mu \mathrm{mol} / \mathrm{g} \text { wet bone })\end{array}$ & $\begin{array}{c}\text { DNA } \\
\text { (mg/g wet bone) }\end{array}$ & $\begin{array}{c}\text { Calcium } \\
\text { ( } \mathrm{mg} / \mathrm{g} \text { bone } a s h)\end{array}$ \\
\hline Control & $1.339 \pm 0.083$ & $0.535 \pm 0.054$ & $1.87 \pm 0.13$ & $315.0 \pm 7.6$ \\
\hline Insulin $10^{-10} \mathrm{M}$ & $1.345 \pm 0.141$ & $0.652 \pm 0.085$ & $2.16 \pm 0.13$ & $341.5 \pm 6.0^{a)}$ \\
\hline Insulin $10^{-9} \mathrm{M}$ & $1.670 \pm 0.051^{a)}$ & $0.743 \pm 0.016^{b)}$ & $3.06 \pm 0.29^{a)}$ & $391.4 \pm 5.6^{b)}$ \\
\hline Insulin $10^{-8} \mathrm{M}$ & $1.855 \pm 0.086^{b)}$ & $0.880 \pm 0.089^{b)}$ & $2.97 \pm 0.21^{b)}$ & $406.6 \pm 7.8^{b)}$ \\
\hline
\end{tabular}

Each value is the mean $\pm \mathrm{SEM}$ of five rats. Femoral-diaphyseal tissues were cultured for $48 \mathrm{~h}$ in a medium containing either vehicle or insulin. $a$ ) $p<0.05, b$ ) $p<0.01$ as compared with the control value.

TABLE II. Effect of Insulin Administration on Bone Components in the Femoral Diaphysis of Rats

\begin{tabular}{|c|c|c|c|c|}
\hline Treatment & & $\begin{array}{l}\text { Alkaline phosphatase } \\
(\mu \mathrm{mol} / \mathrm{min} / \mathrm{mg} \text { protein })\end{array}$ & $\begin{array}{c}\text { DNA } \\
\text { (mg/g wet bone) }\end{array}$ & $\begin{array}{c}\text { Calcium } \\
\text { (mg/g bone ash) }\end{array}$ \\
\hline \multirow[t]{2}{*}{ Normal } & Control & $1.451 \pm 0.059$ & $1.71 \pm 0.06$ & $376.5 \pm 6.5$ \\
\hline & Insulin & $1.701 \pm 0.038^{a)}$ & $2.15 \pm 0.05^{a)}$ & $406.8 \pm 6.3^{a)}$ \\
\hline \multirow[t]{2}{*}{ Skeletal unloading } & Control & $1.098 \pm 0.102^{a)}$ & $1.25 \pm 0.11^{a)}$ & $365.3 \pm 10.4$ \\
\hline & Insulin & $1.256 \pm 0.059$ & $1.46 \pm 0.06$ & $373.4 \pm 8.1$ \\
\hline
\end{tabular}

Rats were subcutaneously administered insulin $(5.0 \mathrm{IU} / 100 \mathrm{~g}$ body weight) 5 times at $24-\mathrm{h}$ intervals, and $1 \mathrm{~h}$ after the last administration they were sacrificed. Each value is the mean \pm SEM of five rats. a) $p<0.01$ as compared with the normal control value without insulin. 
rats, supporting the view that insulin has a stimulatory effect on bone formation and calcification in vivo. Insulin may play a physiological role in the stimulation of bone formation.

The administration of a comparatively higher dose of insulin to rats with skeletal unloading did not stimulate alkaline phosphatase activity, DNA or calcium contents in the femoral diaphysis, although the hormonal effect was seen in normal rats. Thus it is clear that the hormone's stimulation of bone formation is impaired in rats with skeletal unloading in vivo. Presumably, the impairment of this action is important in the deterioration of bone formation in these animals.

It has also been reported that skeletal unloading induces a decrease in the serum level of 1,25-dihydroxyvitamin $D_{3}$, a calcitropic hormone, ${ }^{20)}$ and that it causes a reduction of the bone tissue content of zinc as an activator of bone formation. ${ }^{9)}$ The administration of 1,25-dihydroxyvitamin $\mathrm{D}_{3}$ and zinc sulfate increased alkaline phosphatase activity and DNA content in the femoral diaphysis of rats with skeletal unloading. ${ }^{21)}$ Therefore, the possibility cannot be ruled out that 1,25-dihydroxyvitamin $\mathrm{D}_{3}$ and zinc may partly contribute to the deterioration of bone formation with skeletal unloading.

In conclusion, the findings of this investigation further support the view that skeletal unloading induces an impairment of insulin action on bone formation in vivo. Insulin may play a physiological role in activating the gravitational effect to stimulate bone formation.

\section{References}

1) R. P. Heaney, Am. J. Med., 33, 188 (1962).
2) E. R. Morey, D. J. Baylink, Science, 202, 1138 (1978).

3) C. L. Donaldson, S. B. Hulley, J. M. Vogel, R. S. Hattner, J. H. Bayers, D. E. McMillan, Metabolism, 19, 1071 (1970).

4) R. K. Globus, D. D. Bikle, E. R. Morey-Holton, Endocrinology, 114, 2264 (1984).

5) R. K. Globus, D. D. Bikle, E. R. Morey-Holton, Endocrinology, 118, 733 (1986).

6) Z. F. G. Jaworsky, H. K. Uhthoff, Bone, 7, 431 (1986).

7) M. Yamaguchi, K. Ozaki, T. Hoshi, Res. Exp. Med., 189, 9 (1989).

8) M. Yamaguchi, K. Ozaki, T. Hoshi, Res. Exp. Med., 189, 331 (1989).

9) M. Yamaguchi, K. Sakurai, J. Ohtaki, T. Hoshi, Res. Exp. Med., 191, 273 (1991).

10) R. G. Craig, D. W. Rowe, D. N. Peterson, B. E. Kream, Endocrinology, 125, 1430 (1989).

11) B. E. Kream, M. D. Smith, E. Canalis, L. G. Raisz, Endocrinology, 116, 296 (1985).

12) M. Yamaguchi, H. Oishi, Y. Suketa, Biochem. Pharmacol., 36, 4007 (1987).

13) B. Flanagan, G. Nichols Jr., J. Biol. Chem., 237, 3786 (1962).

14) K. I. Kivirikko, O. Latinen, D. J. Prockop, Anal. Biochem., 19, 249 (1967).

15) G. Ceriotti, J. Biol. Chem., 214, 39 (1955).

16) K. Walter, C. Schutt, "Methods of Enzymatic Analysis," Vol. 1-2, ed. by H. U. Bergmeyer, Academic Press, New York, 1974, pp. $856-860$.

17) O. H. Lowry, N. J. Rosebrough, A. L. Farr, R. J. Randall, J. Biol. Chem., 193, 265 (1951).

18) M. Yamaguchi, T. Hoshi, Res. Exp. Med., 192, 345 (1992).

19) J. R. Levy, E. Murray, S. Manolagas, J. M. Olefsky, Endocrinology, 119, 1786 (1986).

20) B. P. Halloran, D. D. Bikle, T. J. Wronski, R. K. Globus, M. J. Levans, E. R. Morey-Holton, Endocrinology, 118, 948 (1986).

21) M. Yamaguchi, K. Ozaki, T. Hoshi, "Aerospace Science," ed. by K. Yajima, University Research Center, Nihon University, Tokyo, 1989 . pp. $409-415$. 